\title{
PEMANFAATAN LIMBAH CANGKANG TELUR SEBAGAI BIOSORBEN UNTUK ADSORPSI LOGAM Pb Dan Cd
}

\author{
Mamay Maslahat", Agus Taufiq, Prima Wahyu Subagja \\ Jurusan Kimia FMIPA Universitas Nusa Bangsa, Bogor \\ *e-mail: maykulsum@yahoo.co.id
}

\begin{abstract}
Waste Utilization of Eggs Shell as an Adsorbent for Adsorption of Metal, Pb and Cd

Eggshell waste is one of waste that not be fully utilized. Eggshell can be used as a biosorbent substance because its contain a high $\mathrm{CaCO}_{3}$ and has a natural pore structure. Eggshell waste biosorbent potentially used as an alternative to adsorp heavy metal waste that pollute much in the environment. The purpose of the study was to use the waste to become biosorbent and to investigate its potential in adsorption $\mathrm{Pb}$ and $\mathrm{Cd}$. Research methodology were producing biosorbent and getting optimum-sorption condition. They were contact time, biosorbent weights, and the concentration of $\mathrm{Pb}$ and $\mathrm{Cd}$. Measurement of the concentration of $\mathrm{Pb}$ and $\mathrm{Cd}$ before and after sorption processes using instrument of Atomic Absorption Spectrophotometer (AAS) Agilent 240FS type AA. The results showed that eggshell biosorbent could adsorb heavy metals of $\mathrm{Pb} 65.99 \%$ in concentration of adsorbent of $160 \mathrm{ppm}$, contact time was 20 minutes, and biosorbent weights of $0.50 \mathrm{~g}$. Adsorption of Cd was $93.16 \%$ in concentration of adsorbent was 20 ppm, contact time 40 minutes, and biosorbent weights $0.25 \mathrm{~g}$.
\end{abstract}

Key words: eggshell biosorbent, Pb, Cd, Atomic Absorbtion Spectrophotometer

\begin{abstract}
ABSTRAK
Limbah cangkang telur termasuk salah satu limbah yang belum dimanfaatkan secara maksimal Cangkang telur dapat dimanfaatkan sebagai zat penjerap yang baik karena mengandung $\mathrm{CaCO}_{3}$ yang tinggi dan memiliki struktur pori-pori alami. Limbah cangkang telur berpotensi digunakan sebagai biosorben alternatif untuk mengadsorpsi limbah logam berat yang banyak mencemari lingkungan yaitu logam berat $\mathrm{Pb}$ dan $\mathrm{Cd}$. Tujuan penelitian ini adalah memanfaatkan limbah cangkang telur untuk dijadikan biosorben dan meneliti potensinya dalam adsorpsi logam $\mathrm{Pb}$ dan $\mathrm{Cd}$. Tahapan penelitian terdiri atas preparasi dan pembuatan biosorben cangkang telur, dan optimasi adsorpsi biosorben cangkang telur terhadap logam berat $\mathrm{Pb}$ dan $\mathrm{Cd}$. Optimasi adsorpsi meliputi variabel waktu kontak optimum, bobot biosorben optimum, dan konsentrasi adsorbat optimum. Pengukuran konsentrasi logam berat $\mathrm{Pb}$ dan $\mathrm{Cd}$ sebelum dan setelah proses adsorpsi menggunakan instrumen Atomic Absorption Spectrophotometer (AAS) Agilent tipe 240FS AA. Hasil penelitian menunjukan bahwa biosorben cangkang telur dapat mengadsorpsi logam berat Pb sebesar 65,99\% pada kondisi konsentrasi adsorbat 160 ppm, waktu kontak 20 menit, dan berat biosorban sebesar 0,50 gram. Sedangkan untuk logam berat Cd, persen adsorpsi sebesar 93,16\% pada konsentrasi sorbat 20 ppm, waktu kontak 40 menit, dan berat biosorben sebesar 0,25 gram.
\end{abstract}

Kata Kunci: biosorben cangkang telur, $\mathrm{Pb}, \mathrm{Cd}$, Atomic Absorption spectrophotometer.

\section{PENDAHULUAN}

Limbah cangkang telur selama ini hanya dianggap sebagai sampah, dan belum banyak diolah secara maksimal, cangkang telur hanya dimanfaatkan sebagai pakan unggas, pupuk organik, dan baru beberapa industi kecil yang memanfaatkan limbah cangkang telur sebagai bahan baku kerajinan tangan. Cangkang telur memiliki kadar kalsium yang cukup tinggi sehingga memiliki potensi untuk menjadi penyerap atau sorben. Selain itu cangkang telur memiliki struktur berpori dan mengandung asam protein mukopolisakarida yang dapat dikembangkan menjadi suatu adsorben. Gugus penting dalam asam protein mukopolisakarida adalah karboksil, amina, dan sulfat yang dapat mengikat ion logam membentuk suatu ikatan ionik (Surasen, 2002).

Pori-pori alami cangkang telur merupakan zat yang sangat memung- 
kinkan untuk dijadikan adsorben. Lapisan spons dan mammillary membentuk matriks yang terbentuk dari serat-serat protein yang berikatan dengan kalsit (kalsium karbonat), mewakili 90\% dari material cangkang telur. Kedua lapisan tersebut membangun bentuk pori bagi cangkang telur (Carvalho et al., 2011 dalam Paramita, 2012).

Biosorben yang berasal dari limbah cangkang telur dapat digunakan untuk pengolahan limbah hasil industri, yaitu limbah logam berat. Logam berat digolongkan menjadi bahan beracun dan berbahaya (B3), karena bersifat korosif terhadap kulit, beracun, dan karsinogenik. Logam $\mathrm{Pb}$ dan $\mathrm{Cd}$ adalah logam yang banyak mencemari tanah dan perairan dengan konsentrasi yang cukup tinggi dan logam ini dapat terakumulasi dalam tubuh suatu organisme sehingga sangat berbahaya bagi kesehatan manusia (Darmono, 1995)

Biosorben didefinisikan sebagai bahan biologis yang digunakan dalam penjerapan bahan pencemar dari suatu cairan, selanjutnya melalui proses desorpsi bahan ini dapat dibuang dan lebih ramah lingkungan (Suhendrayatna, 2001)

Adsorpsi dapat dimodelkan dengan istilah isoterm yang merupakan fungsi konsentrasi zat terlarut yang terjerap pada padatan terhadap konsentrasi larutan. Persamaan yang biasa digunakan untuk menjelaskan data percobaan isoterm dikaji dan dikembangkan oleh Langmuir, Freundlich, dan Brunauer, Emmet, Teller (BET).

\section{BAHAN DAN METODE}

\section{Alat dan Bahan}

Peralatan yang digunakan yaitu oven, crusher, dan saringan 200 mesh. Tahap analisis yaitu AAS Hitachi Z5000, neraca analitik, erlenmeyer 100 $\mathrm{mL}$, magnetic stirrer, pipet volumetrik $25 \mathrm{~mL}$, pipet serulogi $10 \mathrm{~mL}$, kertas saring, dan piala gelas $150 \mathrm{~mL}$.
Bahan yang digunakan yaitu cangkang telur ayam yang dihaluskan dengan ukuran partikel 200 mesh, larutan standar $\mathrm{Pb} \quad(2 \mathrm{ppm} ; 4$ ppm;8 ppm;12 ppm;16 ppm; dan 20 ppm), larutan standar Cd (0,1 ppm; 0,2 ppm; 0,5 ppm; $1 \mathrm{ppm} ; 2,5 \mathrm{ppm}$; dan $5 \mathrm{ppm}$ ), sampel logam berat $\mathrm{Pb}(5,0$ ppm; 10,0 ppm; 20,0 ppm; 40,0 ppm; 60,0 ppm; 80,0 ppm; 100,0 ppm; 120,0 ppm; 140,0 ppm; 160,0 ppm; 180,0 ppm; 200,0 ppm; dan $250,0 \mathrm{ppm}$ ), dan sampel logam berat $\mathrm{Cd}$ (2,5 ppm; 5,0 ppm; 10,0 ppm; 20,0 ppm; $40,0 \mathrm{ppm} ; 60,0 \mathrm{ppm} ; 80,0 \mathrm{ppm}$; dan $100,0 \mathrm{ppm})$.

\section{Metode}

Limbah cangkang telur dicuci dengan air mengalir sampai bersih, dan dibilas dengan aquades, kemudian dikeringkan dalam oven suhu $40^{\circ} \mathrm{C}$ selama 8 jam, dan ditumbuk sampai halus, kemudian disaring dengan saringan 200 mesh, selanjutnya dikeringkan pada suhu $105^{\circ} \mathrm{C}$ hingga bebas air.

\section{Proses Sorpsi Biosorben Cangkang Telur Terhadap Logam Berat Pb dan Cd}

Penentuan Waktu Kontak Optimum Biosorben Cangkang Telur. Sebanyak $0,25 \mathrm{~g}$ biorsorben cangkang telur dengan ukuran partikel 200 mesh dimasukkan ke dalam $25 \mathrm{ml}$ larutan limbah logam berat dengan konsentrasi 50 ppm (utuk logam $\mathrm{Pb}$ ) dan 2,5 ppm (untuk logam $\mathrm{Cd}$ ), kemudian larutan dikocok dengan stirrer. Adsorpsi dilakukan dengan ragam waktu adsorpsi 5, 10, 20, 30, 40, 50, dan 60 menit. Setelah itu campuran disaring dan filtratnya dibaca pada Spektrofotometer Serapan Atom (SSA) untuk mengetahui adsorpsi maksimum. Waktu optimum ditentukan dengan menghitung kapasitas adsorpsi maksimum.

Penentuan Bobot Optimum Biosorben Cangkang Telur. Variasi bobot biosorben yang digunakan adalah 0,$05 ; 0,10 ; 0,15 ; 0,25 ; 0,50 ; 1,00$ dan 2,00 g. Masing-masing dimasukkan ke dalam $25 \mathrm{ml}$ larutan limbah logam 
beratdengan konsentrasi50 ppm (utuk logam $\mathrm{Pb}$ ) dan 2,5 ppm (untuk logam $\mathrm{Cd}$ ), kemudian dikocok dengan stirrer. Campuran dikocok pada waktu optimum adsorpsi. Campuran disaring dan filtratnya dibaca pada Spektrofotometer Serapan Atom (SSA). Bobot optimum ditentukan dengan menghitung kapasitas adsorpsi maksimum.

Penentuan Konsentrasi Logam Berat (sebagai adsorbat). Erlenmeyer yang berisi bobot optimum biosorben dimasukkan ke dalam $25 \mathrm{ml}$ larutan limbah logam berat pada konsentrasi 5; $10 ; 20 ; 40 ; 60 ; 80 ; 100 ; 120 ; 140 ; 160$; 180; 200; dan 250ppm (untuk logam $\mathrm{Pb}$ ) ppm 2,5; 5; 10; 20; 40; 60; 80; dan 100 ppm Untuk logam Cd), kemudian dikocok dengan stirrer pada waktu optimum. Setelah itu campuran disaring dan filtratnya dibaca pada Spektrofotometer Serapan Atom (SSA).

Kapasitas adsopsi maksimum dari setiap variabel dapat dihitung dengan rumus sebagai beikut:

$$
Q=\frac{V(C o-C a)}{m}
$$

$\mathrm{Q}=$ Kapasitas adsorpsi per bobot biosorben $(\mu \mathrm{g} /$ grambioremoval $)$

$\mathrm{Q}=$ Volume larutan $(\mathrm{ml})$

Co $=$ Konsentrasi awal (ppm)

$\mathrm{Ca}=$ Konsentrasi akhir (ppm)

$\mathrm{m}=$ Bobot biosoren (gram)

Penentuan gugus fungsi biosorben dilakukan dengan menguji sampel bubuk biosorben ukuran 200 mesh menggunakan instrumen spektrofotometer infra red.

\section{HASIL DAN PEMBAHASAN}

Sampel limbah cangkang telur yang diperoleh dari limbah rumah tangga dan rumah makan. Limbah cangkang telur yang digunakan merupakan limbah baru yang belum menghasilkan bau busuk. Cangkang telur yang telah dicuci bersih, kemudian dikeringkan pada suhu $40^{\circ} \mathrm{C}$, kemudian ditumbuk dan disaring dengan ukuran 200 mesh, lalu diaktivasi pada suhu $105^{\circ} \mathrm{C}$ selama 4 jam. Tujuan pengeringan ini adalah untuk menghilangkan molekul air yang terkandung dalam serbuk cangkang telur

Penentuan ukuran partikel dilakukan agar sampel yang digunakan seragam. Dalam proses sorpsi padatancairan ukuran partikel sangat mempengaruhi kapasitas adsorpsi. Ukuran pori dan luas permukaan adsorben merupakan hal yang sangat penting dalam adsorpsi. Luas permukaan adsorben dapat diperbesar dengan cara pengecilan ukuran partikelnya. Semakin kecil ukuran partikel akan memperluas permukaan biosorben sehingga ketersediaan sisi aktif biosorben akan meningkat. Bertambahnya sisi-sisi aktif dari permukaan biosorben dapat memungkinkan adsorpsi terjadi di lebih banyak tempat pada permukaan biosorben. Jumlah permukaan biosorben yang meningkat akan meningkatkan jumlah adsorbat yang terjerap.Cangkang telur memiliki lebih dari 7000-17000 mikropori. Pori-pori alami cangkang telur merupakan zat yang sangat memungkinkan untuk dijadikan adsorben. Lapisan spons dan mammillary membentuk matriks yang terbentuk dari serat-serat protein yang berikatan dengan kalsit (kalsium karbonat), mewakili 90\% dari material cangkang telur. Kedua lapisan tersebut pun membangun bentuk pori bagi cangkang telur (Carvalho et al., 2011).

\section{Sisi Aktif Biosorben}

Biosorben cangkang telur setelah dihaluskan dan dikeringkan kemudian dianalisis gugus aktifnya dengan menggunakan spektrofotomer infra red (IR). Pemerikasaan ini bertujuan untuk mengetahui sisi aktif dari biosorben yang digunakan. Berdasarkan hasil penelitian Paramita (2012) diketahui bahwa spektrum infra merah dari serbuk cangkang telur, seperti tersaji pada Gambar 1. 


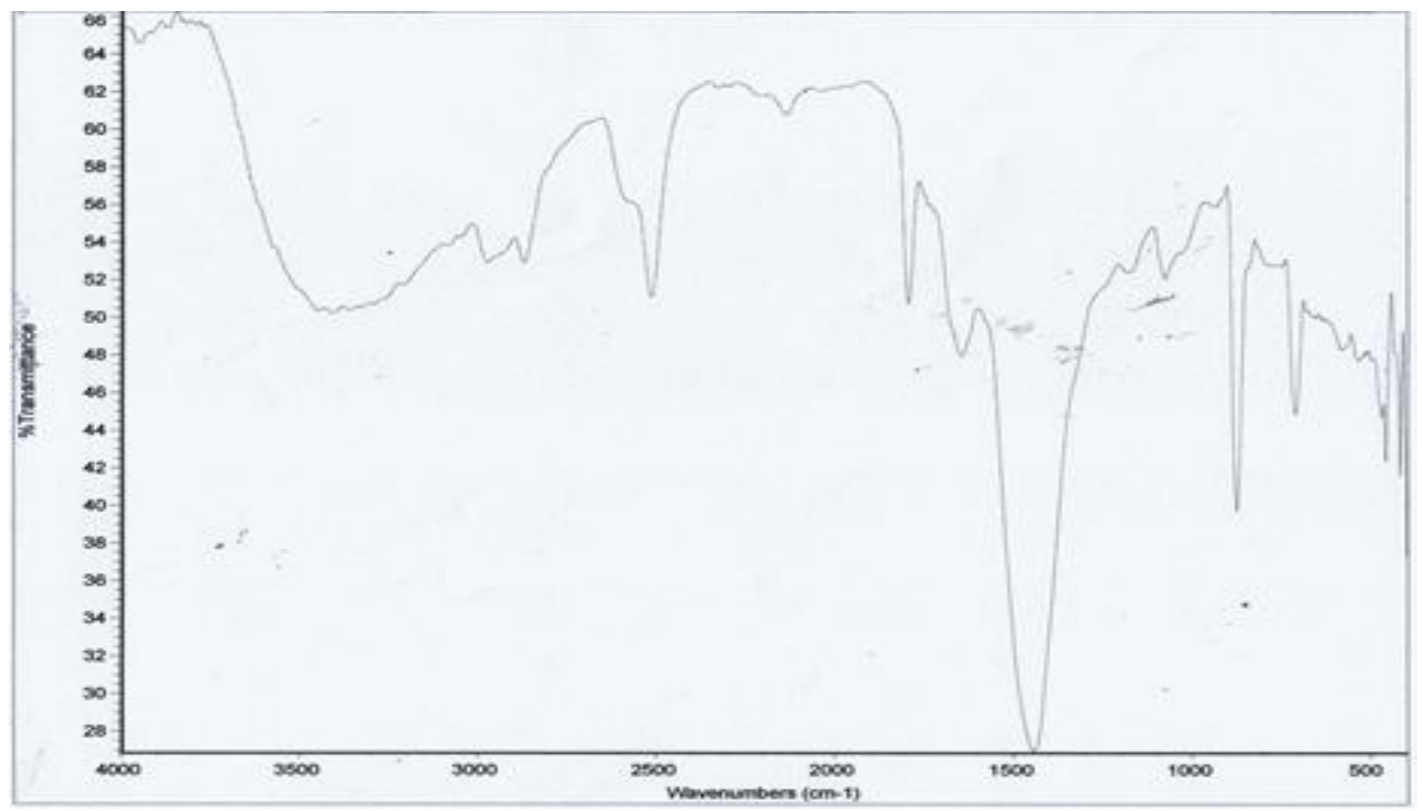

Gambar 1. Spektrum Infra Merah Serbuk Cangkang Telur.

(Sumber: Paramita, 2012)

Interpretasi dari spektrum infra merah pada sampel cangkang telur ini memperlihatkan adanya puncak penyerapan yang signifikan pada $1500-$ $1400 \mathrm{~cm}^{-1}$, berasosiasi dengan kuat atas keberadaan mineral karbonat pada matriks cangkang telur. Puncak serapan pada sekitar $2500 \mathrm{~cm}^{-1}$ dan $1810 \mathrm{~cm}^{-1}$ menunjukkan keberadaan karbonil. Dan dari hasil spektrum teramati bahwa terdapat puncak serapan di sekitar 715 $\mathrm{cm}^{-1}$ dan $875 \mathrm{~cm}^{-1}$ yang masing-masing merupakan pendukung untuk keberadaan kalsium karbonat (Tsai et al., 2006). Sedangkan pada $3500-3200 \mathrm{~cm}^{-1}$ dan $1650 \mathrm{~cm}^{-1}$ yang masing-masing merupakan regang $-\mathrm{NH}$ dan $-\mathrm{NH}-\mathrm{C}=\mathrm{O}$. Ini menunjukkan bahwa cangkang telur pun tersusun atas zat organik, yakni membran cangkang telur. Membran cangkang telur ini tersusun dari sejumlah material organik diantaranya kolagen, asam hianulorik, asam amino, dan polipeptida. Keberadaan struktur poros alami dan permukaan berporinya yang luas, limbah cangkang telur yang banyak mengandung kalsium mudah untuk digiling dan dihaluskan menjadi bubuk, yang kemudian dapat dimanfaatkan sebagai adsorben yang baik yakni berupa porous adsorbent.

\section{Kondisi Optimum Adsorpsi Logam Berat Oleh Biosorben Cangkang Telur Waktu Optimum}

Lamanya proses adsorpsi ditentukan berdasarkan kapasitas adsorpsinya selama rentang waktu tertentu. Saat kapasitas adsorpsi mencapai nilai maksimum, maka lamanya proses adsorpsi tersebut diambil sebagai waktu optimum adsorpsi (Paramita, 2012). Penambahan waktu kontak tidak akan memberikan pengaruh yang signifikan terhadap pengurangan kadar $\mathrm{Pb}$ dan $\mathrm{Cd}$ dalam adsorbat.

Waktu optimum penyerapan logam berat $\mathrm{Pb}$ oleh biosorben cangkang telur terjadi pada menit ke 20, dengan nilai persentase adsorpsi logam $\mathrm{Pb}$ sebesar $99,8701 \%$ pada waktu optimum dan jumlah biosorben 0,25 g (Gambar 2). Nilai kapasitas adsorpsi semakin naik dari menit ke 5 hingga menit ke 10, dan pada menit ke 20 terjadi adsorpsi logam berat $\mathrm{Pb}$ maksimum. Pada menit ke 20 hingga menit ke 60 terjadi penurunan kapasitas adsorpsi dengan nilai yang sangat rendah dan hampir signifikan. 


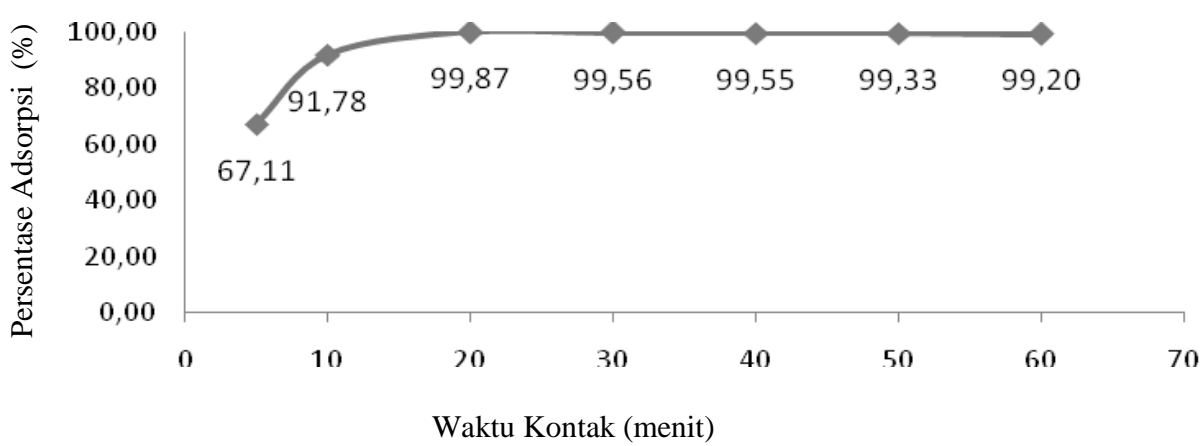

Gambar 2. Waktu Optimum Adsorpsi Logam Berat $\mathrm{Pb}$ oleh Biosorben Cangkang Telur

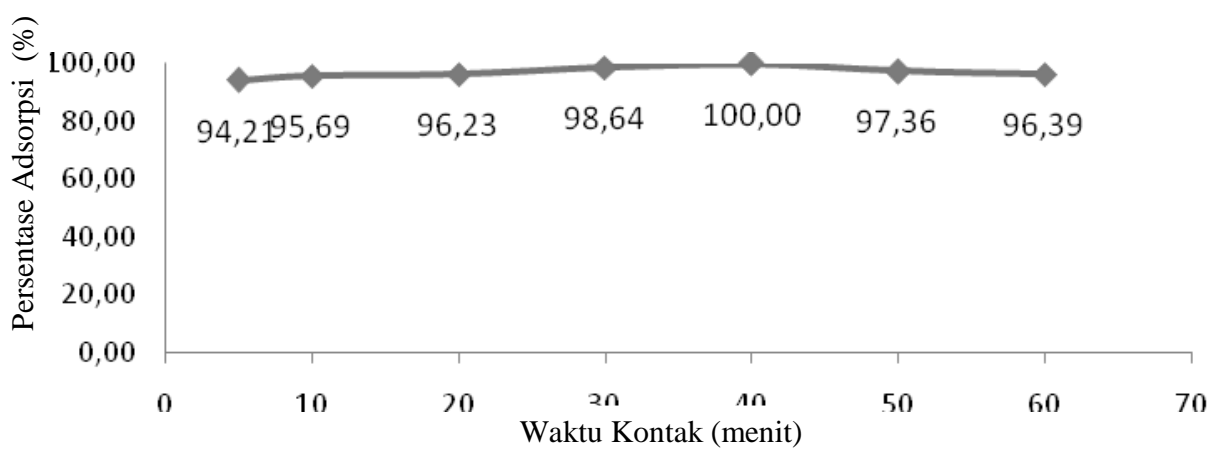

Gambar 3 . Waktu Optimum Adsorpsi Logam Berat Cd oleh Biosorben Cangkang Telur

Waktu optimum penyerapan logam berat $\mathrm{Cd}$ oleh biosorben cangkang telur terjadi pada menit ke 40.Logam berat Cd diserap sempurna oleh biosorben cangkang telur (100\%) pada waktu optimum dan jumlah biosorben $0,25 \mathrm{~g}$ (Gambar 3). Nilai kapasitas adsorpsi semakin naik dari menit ke 5 hingga menit ke 30, dan pada menit ke 40 terjadi adsorpsi logam berat $\mathrm{Cd}$ maksimum.

Peningkatan kapasitas adsorpsi ini terjadi karena adanya pembukaan tapak aktif yang lebih besar sehingga adsorben lebih banyak menyerap adsorbat (Lestari, 2011). Setelah mencapai waktu adsorpsi maksimum, kapasitas adsorpsi cenderung semakin menurun. Hal ini disebabkan oleh jumlah biosorben yang berikatan dengan adsorbat sudah dalam keadaan jenuhnya, sehingga apabila ditambahkan waktu adsorpsi yang berlebih akan menyebabkan terjadinya proses desorpsi atau pelepasan kembali antara biosorben dan adsorbat.

\section{Bobot Optimum}

Pengaruh bobot biosorben terhadap adsorpsi logam Pbdapat dilihat pada Gambar 4. Semakin banyak bobot biosorben yang ditambahkan, persentase penyerapan akan semakin tinggi. Penambahan bobot biosorben lebih dari 0,50 gram tidak memberikan kenaikan kapasitas adsorpsi yang signifikan tehadap logam $\mathrm{Pb}$, hal ini karena penambahan bobot biosorben sebanyak 0,50 gram dapat menyerap logam $\mathrm{Pb}$ dengan sempurna.

Pengaruh bobot biosorben terhadap adsorpsi logam $\mathrm{Cd}$ dapat dilihat pada Gambar 5. Kapasitas adsorpsi optimum diperoleh dengan bobot biosorben sebanyak 0,25 gram. Sama hal nya dengan adsorpsi logam $\mathrm{Pb}$, penambahan bobot biosorben lebih dari 0,25 gram tidak memberikan kenaikan kapasitas adsorpsi yang signifikan tehadap logam $\mathrm{Cd}$, hal ini karena penambahan bobot biosorben sebanyak 0,25 gram dapat menyerap logam Cd dengan sempurna.

Peningkatan kapasitas adsorpsi disebabkan oleh jumlah pembukaan 
tapak aktif yang lebih besar sehingga biosorben lebih banyak menjerap adsorbat dan kapasitas adsorpsi akan meningkat sampai tercapainya bobot optimum. Setelah kondisi optimum, tidak tampak terjadi penyerapan yang signifikan. Hal ini disebabkan sudah tidak ada lagi adsorbat yang dijerap sehingga penambahan biosorben sampai kondisi tertentu tidak akan memberi dampak pada peningkatan kapasitas adsorpsi. Bertambahnya berat biosorben sebanding dengan bertambahnya jumlah partikel dan luas permukaan biosorben sehingga menyebabkan jumlah tempat mengikat ion logam juga bertambah dan efisiensi penyerapan pun meningkat (Refilda, 2001). Hal ini juga mengindikasikan bahwa makin banyak pori yang dimiliki oleh biosorben sehingga kecepatan adsorpsi semakin meningkat. Menurut Barros (2003), pada saat ada peningkatan bobot adsorben, maka ada peningkatan persentase penjerapan dan penurunan kapasitas adsorpsi.

\section{Konsetrasi Optimum}

Pengaruh konsentrasi adsorbat terhadap adsorpsi oleh biosorben cangkang telur dapat dilihat pada Gambar 6. Kapasitas adsorpsi optimum diperoleh pada konsentrasi logam berat $\mathrm{Pb} 160$ ppm yakni sebesar 65,9859\%. Penambahan konsentrasi adsorbat lebih dari 160 ppm menyebabkan kapasitas adsorpsi cenderung menurun.

Kapasitas adsorpsi optimum pada konsentrasi logam berat $\mathrm{Cd}$ adalah 20 ppmyakni sebesar 93,1616\% (Gambar 7). Penambahan konsentrasi adsorbat lebih dari 20 ppm menyebabkan kapasitas adsorpsi cenderung menurun. Menurut Zou et al.,(2006) kecepatan adsorpsi dan kapasitas adsorben dipengaruhi oleh konsentrasi ion logam dalam limbah cair. Semakin semakin besar konsentrasi menyebabkan penurunan kapasitas adsorpsi pada adsorben.

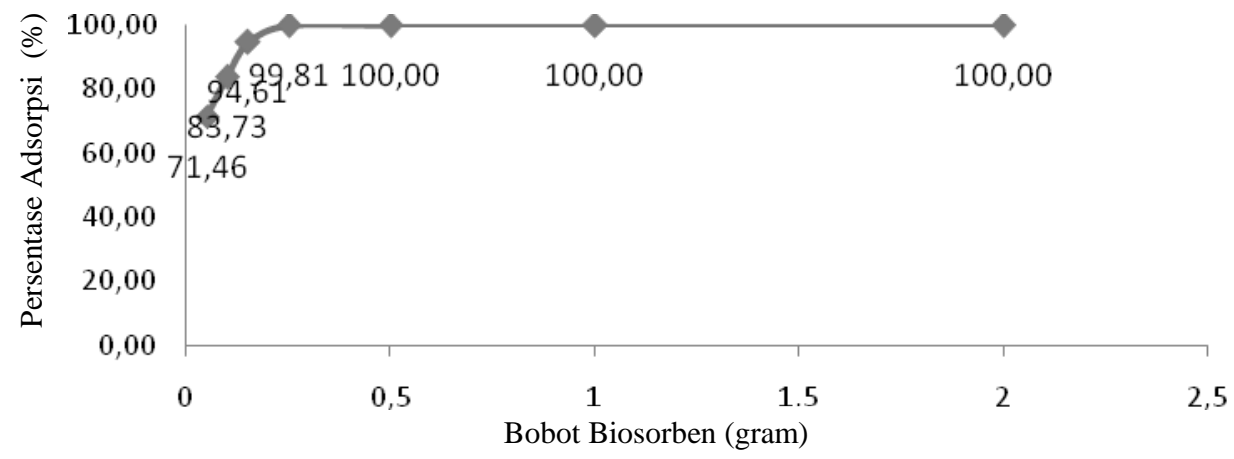

Gambar 4. Bobot Optimum Adsorpsi Logam Berat $\mathrm{Pb}$ oleh Biosorben Cangkang Telur

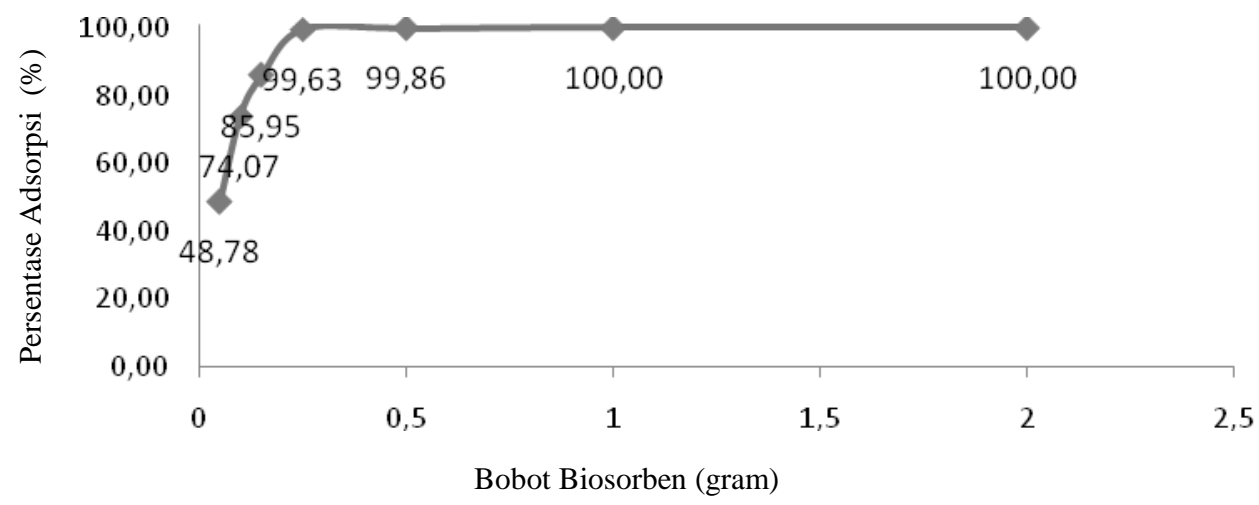

Gambar 5. Bobot Optimum Adsorpsi Logam Berat Cd oleh Biosorben Cangkang Telur 


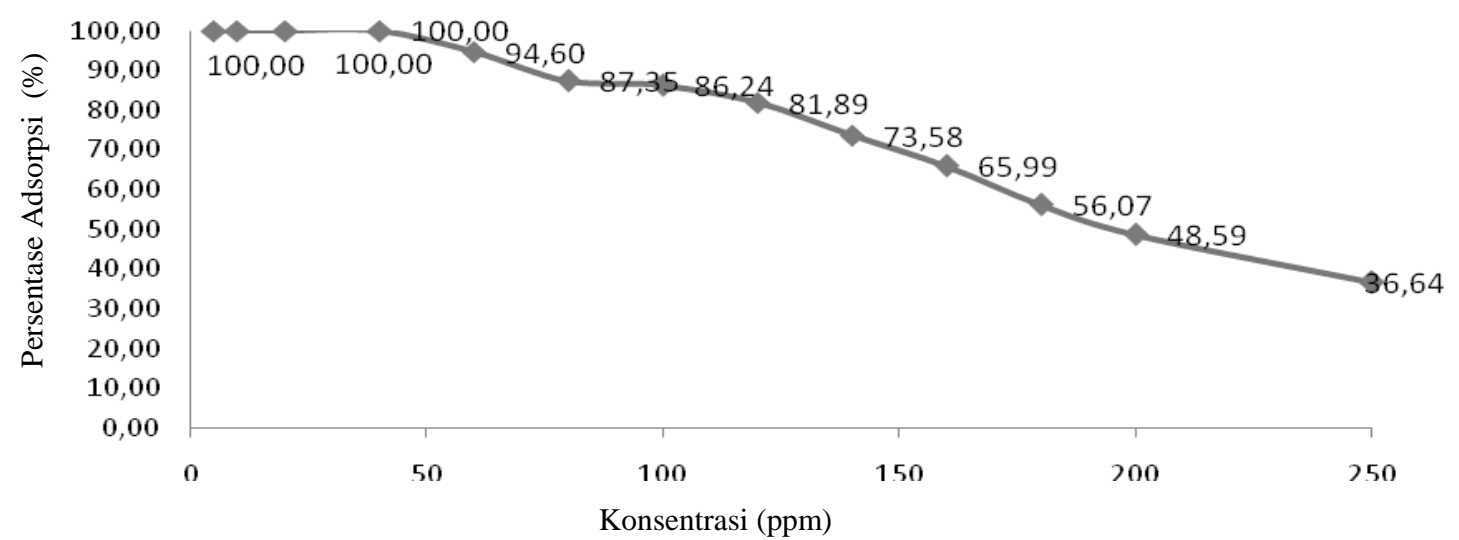

Gambar 6. Konsentrasi Optimum Logam Berat Pb oleh Biosorben Cangkang Telur

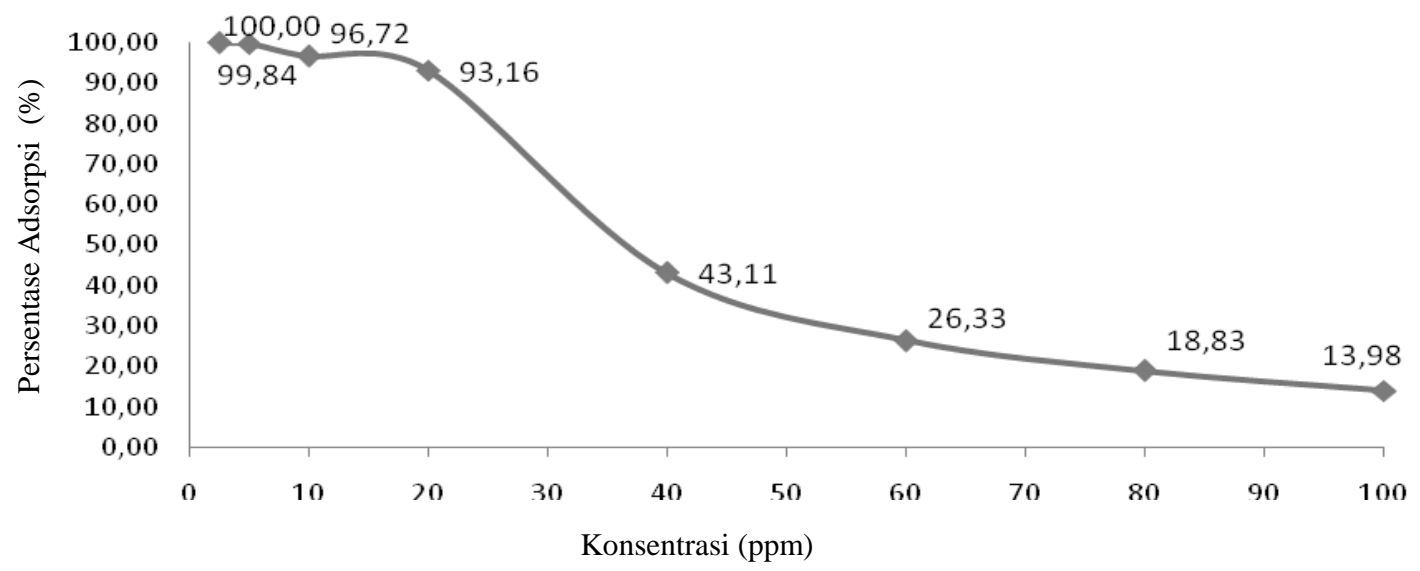

Gambar 7. Konsentrasi Optimum Logam Berat Cd oleh Biosorben Cangkang Telur

Adsorbat yang digunakan adalah larutan tunggal logam berat $\mathrm{Pb}$ dan $\mathrm{Cd}$, hal ini merupakan simulasi dari limbah industri yang mengandung logam berat $\mathrm{Pb}$ dan $\mathrm{Cd}$. Proses adsorpsi dilakukan berdasarkan kondisi optimum masingmasing biosorben. Perlakuan pada kondisi waktu dan bobot optimum. Kapasitas adsorpsi biosorben cangkang telur dengan logam berat $\mathrm{Pb}$ lebih tinggi dibandingkan dengan kapasitas adsorpsi biosorben cangkang telur dengan logam berat Cd. Dimana kemampuan penyerapan optimum biosorben cangkang telur terhadap logam berat $\mathrm{Pb}$ terjadi pada konsentrasi 160 ppm, sedangkan kemampuan penyerapan optimum biosorben cangkang telur terhadap logam berat $\mathrm{Cd}$ pada konsentrasi $20 \mathrm{ppm}$.

\section{Adsorpsi Ion $\mathrm{Pb}^{2+}$ dan $\mathrm{Cd}^{2+}$}

Ion $\mathrm{Pb}^{2+}$ dan $\mathrm{Cd}^{2+}$ dipilih karena ion $\mathrm{Pb}^{2+}$ memiliki muatan yang sama dengan $\mathrm{Cd}^{2+}$ dan juga termasuk logam berat pencemar yang berbahaya. Namun ion $\mathrm{Pb}^{2+}$ dan $\mathrm{Cd}^{2+}$ memiliki nomor atom, nomor massa atom relatif, periode, golongan, dan muatan inti efektif yang berbeda yang menimbulkan terjadinya kompetisi antara $\mathrm{Pb}^{2+}$ dan $\mathrm{Cd}^{2+}$.

Biosorben cangkang telur menyerap lebih banyak ion logam $\mathrm{Pb}^{2+}$ dibandingkan $\mathrm{Cd}^{2+}$. Hal ini karena ion logam $\mathrm{Pb}^{2+}$ memiliki massa molekul relatif yang lebih tinggi dibandingkan massa molekul relatif $\mathrm{Cd}^{2+}$, sehingga $\mathrm{Pb}^{2+}$ lebih cepat jatuh (sampai) ke permukaan biosorben dan terjerap pada biosorben dibandingkan $\mathrm{Cd}^{2+}$. Ion $\mathrm{Pb}^{2+}$ memiliki jari-jari ion yang lebih besar dari ion $\mathrm{Cd}^{2+}$ sehingga memiliki gaya elektrostatik yang relatif kecil dan 
menyebabkan kemampuan ion $\mathrm{Pb}^{2+}$ menarik molekul air disekitarnya lemah. Dengan lemahnya kemampuan $\mathrm{Pb}^{2+}$ dalam menarik molekul air, maka jarijari hidrasinya yang dimiliki menjadi lebih kecil dan mobilitas atau pergerakan ion $\mathrm{Pb}^{2+}$ dalam air makin tinggi (cepat), sehingga ion $\mathrm{Pb}^{2+}$ lebih mudah sampai kepermukaan adsorben. Selain itu, $\mathrm{Pb}^{2+}$ memiliki nomor atom lebih besar dari pada $\mathrm{Cd}^{2+}$ yang menunjukkan jumlah proton yang dimiliki oleh $\mathrm{Pb}^{2+}$ lebih besar dari pada $\mathrm{Cd}^{2+}$. Jumlah proton dalam $\mathrm{Pb}^{2+}$ yang lebih besar dari $\mathrm{Cd}^{2+}$ ini mengakibatkan daya tarik inti dan muatan inti efektif yang dimiliki $\mathrm{Pb}^{2+}$ lebih besar sehingga akanlebih mempermudah $\mathrm{Pb}^{2+}$ dalam menginduksi biosorben cangkang telur yang bersifat non polar dan membentuk gaya tarik elektrostatik yang di sebut gaya dipoldipolinduksian (Lailiyahet al., 2000). Biosorben cangkang telur memiliki kemampuan adsorpsi ion logam berat $\mathrm{Pb}^{2+}$ dan $\mathrm{Cd}^{2+}$. Hal ini karena secara bentuk struktur atau bentuk topologi permukaan, biosorben cangkang telur memiliki ukuran diameter ruang kosong yang besar sehingga ion $\mathrm{Pb}^{2+}$ dan $\mathrm{Cd}^{2+}$ mudah masuk danberinterakasi ke dalam ruang kosong biosorben cangkang telur.

Pada penelitian Sugiarti dan Allo (2009), kapasitas adsorpsi logam berat oleheceng gondok, baik dalam larutan media yang hanya ditambahkan satu logam saja $\mathrm{Pb}$ atau $\mathrm{Cd}$ maupun dalam larutan media yang ditambahkan dua jenis logam campuran $\mathrm{Pb}$ dan $\mathrm{Cd}$, penyerapan oleh eceng gondok terhadap masing-masing logam berat $\mathrm{Cd}$ dan $\mathrm{Pb}$ relatifsaling mempengaruhi, sehingga kemampuan eceng gondok menyerap larutan yang berisi logam tunggal, relatif lebih tinggi dari pada larutan yang berisi campuran logam $\mathrm{Cd}$ dan $\mathrm{Pb}$.

\section{KESIMPULAN}

Biosorben cangkang telur dapat mengadsorpsi logam berat $\mathrm{Pb}$ dan $\mathrm{Cd}$. Persentase adsorpsi untuk logam berat $\mathrm{Pb}$ sebesar 65,99\% dengan konsentrasi logam berat $\mathrm{Pb} 160$ ppm, waktu kontak 20 menit, dan bobot biosorben $0,50 \mathrm{~g}$. Persentase adsorpsi untuk logam berat Cd sebesar 93,16\% dengan konsentrasi logam berat Cd 20 ppm, waktu kontak 40 menit, dan bobot biosorben $0,25 \mathrm{~g}$.

\section{DAFTAR PUSTAKA}

Barros, L.M., G.R. Maedo, M.M.L. Duarte, E.V. Silva, dan Lobato. 2003. Biosorption of Cadmium Using the Fungus Aspergillus Niger. Brazilian Journal Chemical. 20 (3).

Carvalho, A.F.U., D.F. Farias, C.X. Barroso, C.M.L. Sombra, A.S. Silvino, M.O.T. Menezes, M.O. Soares, D.A.O. Fernandes, dan S.T. Gouveia. 2011. Adsorption Process onto an Innovative Eggshell-derived Low-Cost Adsorbent in Stimulated Effluent and Real Industrial Effluents. Wastes: Solutions, Treatments and Opportunities, $1^{\text {st }}$ International Conference.

Darmono. 1995. Logam Dalam Sistim Biologi Mahluk Hidup. Universitas Indonesia Jakarta.

Lestari, S. 2011. Pemanfaatan Limbah Tandan Kosong Kelapa Sawit (TKKS) sebagai Biosorben Fenol. Skripsi. Universitas Nusa Bangsa. Bogor.

Paramita, M. 2012. Pemanfaatan Limbah Tandan Kosong Kelapa Sawit (TKKS) Modifikasi Cangkang Telur (CT) sebagai Biosorben Fenol. Skripsi. Universitas Nusa Bangsa. Bogor. 
Refilda. 2001. Pemanfaatan Ampas Tebu Sebagai Bahan Alternatif Pengganti Penyerap Sintetik Logam-logam Berat Pada Air Limbah. Skripsi. Universitas Andalas. Padang.

Sugiarti, dan E.L. Allo. 2009. Pengaruh Konsentrasi $\mathrm{Cd}, \mathrm{Pb}$ dan Lama Penanaman Terhadap Penyerapan Eceng Gondok (Eichhornia Crassipes). FMIPA Universitas Negeri Makasar. Makasar.

Suhendrayatna. 2001. Heavy Metal Bioremoval by Microorganisma Literature Study. Bioteknologi Untuk Indonesia Abad 21.

Surasen, C. 2002. Removal of Cadmium in Synthetic Wastewater by Egg Shell Filter. Tesis. Faculty of Graduate Studies, Kasetsart University. Bangkok

Zou, W., R. Han, Z. Chen, Z. Jinghua, J. dan Shi. 2006. Kinetic Study of Adsorption of $\mathrm{Cu}(\mathrm{II})$ and $\mathrm{Pb}$ (II) from Aqueous Solutions Using Manganese Oxide Coated Zeolite in Batch Mode. Journal of Colloids and Surfaces. 279(1-3): 238-246. 